\title{
Response of Jerusalem artichoke Plants to Organic Fertilizers and Humic Acid in Reclaimed Soil at South Egypt
}

\author{
Mohamed H.E.
}

Hort. Res. Inst., Agric. Res. Center, Giza, Egypt

\author{
Received: 10 Nov. 2020 / Accepted 20 Dec. 2020 / Publication date: 25 Dec. 2020
}

\begin{abstract}
This work was carried out during the two successive summer seasons of 2018 and 2019 at Sohag Governorate, Egypt under reclaimed soil to study the interaction between organic manure and humic acid application methods on the productivity, growth, yield and its components as well as the chemical tubers content of Jerusalem artichoke plants. This study included 12 treatments which were the combinations between four rates of organic manure $(0,5,10$ and 15 ton/fed) and three humic application methods (spraying, soil addition and both of them together). The obtained results indicated that, the organic manure at rate 15 ton/fed gained the highest plant, No. of stems/plant, fresh weight/plant, total yield, average tuber weight and dry matter of tuber percentage as well as, chemical contained of NPK and inulin in tubers compared to other rates in both seasons. Application of humic acid increased the most parameters under this study in both seasons. Spraying humic acid + soil application given superior results in most parameters compared to spraying or soil addition as sole treatment. The interaction between organic manure rates and humic acid applications significantly affected growth, yield and its components. The best treatment observed in this study was blend of organic manure application at rate of $15 \mathrm{ton} / \mathrm{fed}$. with the use of humic acid as spraying plus soil addition treatment in most studied parameters in both seasons.
\end{abstract}

Keywords: Jerusalem artichoke, Humic acid and reclaimed soil

\section{Introduction}

Helianthus tuberosus L. (family Asteraceae) also, known as Jerusalem artichoke or sun-choke is originally from north America being one of the few crops taken from new world to Europe Asia (Seiler, 2004). Jerusalem artichoke is known with rich in inulin (Monti, et al., 2005 and Tassoni, et al., 2010). Also crop is a healthy choice for diabetics, therefore mainly cultivated as a vegetable, but also utilized as fodder crop and source of inulin for food and industrial proposes (Kays and Nottinghan, 2008).

The organic fertilizers improved soil texture and this in turn encouraged the plant to have a good root development through improving the aeration of the soil which released phytohormons that may stimulated the plant growth and absorption of nutrients (Reyndrs and Viassak, 1982). Such improved conditions of the soil leads to a higher yield and good quality (Borin, et al., 1987). Moreover, many works investigated the benefit role of organic matter in the soil (Cooke, 1972, Maynard, 1989 and Hallorans, et al., 1993). Organic matter had consultable effect on increasing yield and dry matter of potato tubers (Sharma and Arora, 1990). The plant height, NPK content in tuber and weight of potato tuber/plant, total tubers yield and dry matter content were significantly increased with increasing organic manure up to $30 \mathrm{~m}^{3} / \mathrm{fed}$. El-Sharkawy (2003) found that tuber yield and inulin, total sugar, protein and NPK content of Jerusalem artichoke increased as organic matter level elevated from 10, 20 and $40 \mathrm{~m}^{3}$. The highest vegetative growth characters, total tuber yield and tuber weight of Jerusalem artichoke were the plants fertilizers by $12 \mathrm{~m}^{3} /$ fed. chicken manure (Ragab, et al., 2008). Anwar, et al., (2011) found that, organic fertilizers at a level of $40 \mathrm{~m}^{3} /$ fed. match maximum values of plant height, No. of shoots/plant, fresh and dry weight/plant and increased No. of tubers/plant, tuber weight, yield and chemical contents of Jerusalem artichoke tubers as a compared with $10 \mathrm{~m}^{3} / \mathrm{fed}$.

Since our soils having low organic matter content and higher soil PH levels, application of humic acid can play a good role increasing the yield of Jerusalem artichoke, and improve its quality. Hafez (2003) and El-Desuky (2004) declared that, humic acid application led to significantly increase in plant growth and crop yield as result of improvement of soil organic matter content. Verlinden, et al., (2009) and Selim, et al., (2011) mentioned that, humic acid increased potato tuber yield and quality. Soil

Corresponding Author: Mohamed H.E., Hort. Res. Inst., Agric. Res. Center, Giza, Egypt 
application of humic acid to sweet potato enhanced plant growth characters, total yield and tuber root quality (El-Sayed Hamada, et al., 2011). Eid (2013) notes that, the humic acid increased the tuber yield, fresh and dry weight of Jerusalem artichoke shoots. Application of humic acid at $1 \mathrm{~g} / \mathrm{L}$ as soil application increased dry weight of shoots, No. of tuber, yield/plant and total yield per fed. as well as chemical concentration and inulin contents of Jerusalem artichoke (Samy et al., 2015).

The main objective of this work was to study the effect of both organic manure and humic acid application methods on growth yield, tuber quality and chemical content of Jerusalem artichoke plant grown in reclaimed soil at south Egypt.

\section{Materials and Methods}

This study was conducted on sandy lands at Johina, Sohag Governorate, during 2018 and 2019 seasons to study the response of Jerusalem artichoke plants (Local cultivar) to organic fertilizers (cattle manure) and humic acid application. Soil characteristics are shown in Table (1). Each experiment included 12 treatments, which were the combinations between four levels of organic manure, i.e., $0,5,10$ and 15 ton/fed. and three humic acid application methods i.e., spraying (at $2 \mathrm{~g} / \mathrm{L}$.), soil application (2 $\mathrm{g} / \mathrm{L}$.) and spraying $(1 \mathrm{~g} / \mathrm{L}$. $)+$ soil application $(1 \mathrm{~g} / \mathrm{L}$.), this source of humic acid was taken from the commercial fertile (Humi Power which containing humic acid $80 \%$, Fulvic acid $12 \%$ and Potassium humate $8 \%$ ). Organic manure analysis is presented in Table (2). The organic manure was applied during soil preparation while, the humic acid application methods were applied in two equal partition at 90 and 120 days after planting date. These treatments were arranged in sub-plot design with three replicates having the organic manure treatments in the main plots and the humic acid application methods were arranged randomly in the sub-plots. The experimental unit size was $10.5 \mathrm{~m}^{2}(3 \mathrm{X} 3.5 \mathrm{~m})$ and consisted of the five ridges $3 \mathrm{~m}$ in length and $0.7 \mathrm{~m}$ in width.

Jerusalem artichoke tubers (seed tubers) were planted at $0.5 \mathrm{~m}$ apart the $5^{\text {th }}$ and $6^{\text {th }}$ of April of 2018 and 2019 seasons, respectively.

All experimental plots were fertilized with $25 \mathrm{~kg} \mathrm{~N} /$ fed. as ammonium nitrate $(33.5 \% \mathrm{~N})$ in three equal doses after 60, 90 and 120 days from planting date. Calcium supper phosphate (15.5\%) was added during land preparation at rate $30 \mathrm{Kg} \mathrm{P}_{2} \mathrm{O}_{5}$, as well as potassium sulphate $\left(48 \% \mathrm{~K}_{2} \mathrm{O}\right)$ was applied in two equal partitions at 60 and 90 day from sowing at rate $48 \mathrm{Kg} \mathrm{P} / \mathrm{fed}$. The other agricultural practices were applied according to the recommendation.

Table 1: Soil characterization for the experimental site.

\begin{tabular}{ccccccccccc}
\hline Season & $\begin{array}{c}\text { Texture } \\
\text { grade }\end{array}$ & $\begin{array}{c}\text { Sand } \\
\mathbf{\%}\end{array}$ & $\begin{array}{c}\text { Silt } \\
\mathbf{\%}\end{array}$ & $\begin{array}{c}\text { Clay } \\
\mathbf{\%}\end{array}$ & $\begin{array}{c}\mathbf{p H} \\
\mathbf{( 1 : 1 )}\end{array}$ & $\mathbf{C a C O}_{3}$ & $\begin{array}{c}\text { Total } \\
\mathbf{N \%}\end{array}$ & $\begin{array}{c}\mathbf{P} \\
(\mathbf{p p m})\end{array}$ & $\begin{array}{c}\mathbf{K} \\
(\mathbf{m g} / \mathbf{1 0 0 g})\end{array}$ & $\begin{array}{c}\text { Organic } \\
\text { minor\% }\end{array}$ \\
\hline 2018 & Sandy & 91.1 & 5.7 & 3.2 & 8.01 & 29.14 & 0.05 & 3.33 & 0.32 & 0.09 \\
2019 & Sandy & 92.3 & 4.6 & 3.1 & 8.06 & 30.15 & 0.04 & 3.25 & 0.28 & 0.08 \\
\hline
\end{tabular}

Samples of the soil were obtained from $0.30 \mathrm{~cm}$ soil surface

Table 2: Chemical analysis of the used organic manure (cattle manure)

\begin{tabular}{cccccc}
\hline Organic manure & Organic matter & PH & N\% & P\% & K\% \\
\hline & 37.15 & 7.13 & 0.72 & 0.52 & 0.65 \\
\hline
\end{tabular}

\section{Data were recorded on the following traits:}

During growth period, five plants randomly were taken from each experimental plot (130 days after planting date) to determine the stem length (m), No. of stems/plant and fresh weight of plant $(\mathrm{Kg})$. Jerusalem artichoke plants were harvested on the $18^{\text {th }}$ and $20^{\text {th }}$ of October 2018 and 2019 seasons respectively, yield/plot was recorded and converted to total yield(ton/fed.). Five plants from each subplot were randomly taken to measure the character, i.e. weight tubers/plant (Kg), average weight of tubers $(\mathrm{g})$ and dry matter percentage of tubers.

Nitrogen, Phosphorus and Potassium percentage in the dry matter of tubers were determined according to methods described by Koch and Mc-Meekin (1924), Troug and Meyer (1939) and Brown and Lilleland (1946) for Nitrogen, Phosphorus and Potassium percentage, respectively. Tuber inulin content was determined according to the methods of Winton and Winton (1958).

The data were statistically analyzed by the analysis of variance according to Gomaz and Gomaz (1984) and means separation were done according to LSD at 5\% level of significance. 


\section{Results and Discussion}

\section{Growth, yield and its components:}

\subsection{Effect of organic manure.}

Data in Table (3) showed that, the stem length, No. of stems/plant and fresh weight/plant, yield, weight of tuber and dry matter\% of tubers were significantly affected, in both growth seasons by organic manure level application with no significant differences were observed rate of 5, 10 and 15 ton/fed treatments in both number lateral stems/plant and fresh weight of lateral stems/plant in both seasons. The maximum vegetative growth was obtained from application of 15 ton/fed organic manure compared to the other tested treatments. It is clear that, from the results in the same Table (3), organic manure applications significantly affected yield (ton/fed.), weight tubers/plant, average tuber weight and dry matter $\%$ with no significant between the heaviest applications treatments (10 and 15 ton/fed.) on tuber fresh weight/plant, average and dry matter of tubers percentage in both seasons.

Such effects of the above mentioned treatments could be attributed to the effect of organic manure in improving soil fertility and consequently plant development due to releasing of certain nutrient as well as, increasing water retention especially under sandy soil condition. These results agree with ElSharkawy (2003), Ragab et al., (2008) and Anwar et al., (2011) on Jerusalem artichoke plant, also agree with Sharma and Arora (1990) and Arisha and Bardisi (1999) on Potato.

Table 3: Effect of organic manure (OM) on growth, yield and quality of Jerusalem artichoke at 2018 and 2019 seasons.

\begin{tabular}{|c|c|c|c|c|c|c|c|}
\hline $\begin{array}{l}\quad \text { Traits } \\
\text { OM } \\
\text { (ton/fed) } \\
\end{array}$ & $\begin{array}{c}\text { Stem } \\
\text { length }(m)\end{array}$ & $\begin{array}{l}\text { No. lateral } \\
\text { stems/plant }\end{array}$ & $\begin{array}{c}\text { Fresh weight of } \\
\text { lateral } \\
\text { stems/plant (kg) }\end{array}$ & $\begin{array}{c}\text { Total } \\
\text { yield } \\
\text { (Ton/fed) }\end{array}$ & $\begin{array}{c}\text { Tuber fresh } \\
\text { weight/plant } \\
(\mathrm{kg})\end{array}$ & $\begin{array}{c}\text { Tuber } \\
\text { fresh } \\
\text { weight }(g)\end{array}$ & $\begin{array}{c}\text { Tuber } \\
\text { dry } \\
\text { matter\% }\end{array}$ \\
\hline \multicolumn{8}{|c|}{2018 season } \\
\hline $\mathbf{0}$ & 1.76 & 6.79 & 2.086 & 9.358 & 1.458 & 36.50 & 22.78 \\
\hline 5 & 1.87 & 7.59 & 2.231 & 10.499 & 1.615 & 40.46 & 23.08 \\
\hline 10 & 1.88 & 7.71 & 2.280 & 11.302 & 1.747 & 44.16 & 23.33 \\
\hline 15 & 1.92 & 7.74 & 2.362 & 11.963 & 1.853 & 46.83 & 23.64 \\
\hline LSD $_{0.05}$ & 0.09 & 0.23 & 0.047 & 0.132 & 0.112 & 3.41 & 0.31 \\
\hline \multicolumn{8}{|c|}{2019 season } \\
\hline $\mathbf{0}$ & 1.64 & 6.37 & 1.722 & 8.975 & 1.367 & 33.45 & 21.72 \\
\hline 5 & 1.76 & 6.53 & 1.905 & 9.968 & 1.512 & 36.90 & 22.11 \\
\hline 10 & 1.82 & 6.77 & 2.035 & 10.822 & 1.675 & 41.48 & 22.45 \\
\hline 15 & 1.85 & 7.29 & 2.112 & 11.325 & 1.737 & 43.04 & 22.54 \\
\hline LSD $_{0.05}$ & 0.06 & 0.33 & 0.037 & 0.307 & 0.095 & 2.03 & 0.25 \\
\hline
\end{tabular}

\subsection{Effect of humic acid application}

Table (4) showed the effect of humic acid application on growth yield and quality of tubers of Jerusalem artichoke plant. It is clear from the obtained data that, the humic acid significantly affected most of the studied traits in both seasons. The highest value was detected for the treatment of spraying with soil addition of humic acid for all tested characters except plant height and No. of stems/plant. The lowest values were received when plants were sprayed with humic acid in most studied characters. Also results showed that different additions of humic acid had no significant effect on stem length and number of lateral stems/plant in both seasons. This positive effect of humic acid application was previously discussed by Mengel and Kirkby (1978) who reveal the effect of humic acid to role in cell wall synthesis, cell division, cell development and auxin metabolisms. These results are similar to the results of Hafez (2003), El-Desuky (2004), Jafari-Jood et al., (2013) and Samy et al., (2015).

\subsection{The interaction effect:}

The interaction between organic manure and humic acid application (Table 5) significantly affected all vegetative growth, yield and yield components traits except No. of stems/plant in both seasons. Thus, the highest values were noticed when Jerusalem artichoke plants received 15 ton/fed of organic manure and humic acid as soil addition with spraying for most studied characters at both growing seasons. While, the lowest values were recorded in zero organic manure with spraying of humic acid for all characters in both seasons, except number of lateral stems/plant in the second season. 
Table 4: Effect of humic acid application on growth, yield and quality of Jerusalem artichoke at 2018 and 2019 seasons.

\begin{tabular}{|c|c|c|c|c|c|c|c|}
\hline $\begin{array}{l}\text { Traits } \\
\text { Humic } \\
\text { App. }\end{array}$ & $\begin{array}{c}\text { Stem } \\
\text { length } \\
(\mathbf{m})\end{array}$ & $\begin{array}{c}\text { No. lateral } \\
\text { stems/plant }\end{array}$ & $\begin{array}{c}\text { Fresh weight of } \\
\text { lateral } \\
\text { stems/plant } \\
(\mathrm{kg}) \\
\end{array}$ & $\begin{array}{c}\text { Total } \\
\text { yield } \\
\text { (Ton/fed) }\end{array}$ & $\begin{array}{c}\text { Tuber fresh } \\
\text { weight/plant } \\
(\mathrm{kg})\end{array}$ & $\begin{array}{c}\text { Tuber } \\
\text { fresh } \\
\text { weight } \\
\text { (g) }\end{array}$ & $\begin{array}{c}\text { Tuber } \\
\text { dry } \\
\text { matter\% }\end{array}$ \\
\hline \multicolumn{8}{|c|}{2018 season } \\
\hline Spraying & 1.78 & 7.48 & 2.106 & 10.421 & 1.586 & 39.85 & 22.29 \\
\hline Soil App. & 1.87 & 7.46 & 2.249 & 10.764 & 1.668 & 41.95 & 23.60 \\
\hline $\begin{array}{l}\text { Spraying+ } \\
\text { Soil App. }\end{array}$ & 1.92 & 7.44 & 2.366 & 11.156 & 1.751 & 44.18 & 23.72 \\
\hline LSD $_{0.05}$ & NS & NS & 0.093 & 0.207 & 0.102 & 2.91 & 0.25 \\
\hline \multicolumn{8}{|c|}{2019 season } \\
\hline Spraying & 1.69 & 6.72 & 1.894 & 9.995 & 1.536 & 38.01 & 20.74 \\
\hline Soil App. & 1.75 & 6.73 & 1.949 & 10.309 & 1.571 & 38.77 & 22.70 \\
\hline Spraying+ & 1.88 & 6.80 & 1.998 & 10.514 & 1.612 & 39.38 & 23.18 \\
\hline Soil App. & & & & & & & \\
\hline LSD $_{0.05}$ & NS & NS & 0.035 & 0.201 & 0.051 & 2.31 & 0.27 \\
\hline
\end{tabular}

Table 5: Effect of the interaction between organic manure (OM) and humic acid application on growth, yield and quality of Jerusalem artichoke at 2018 and 2019 seasons.

\begin{tabular}{|c|c|c|c|c|c|c|c|c|}
\hline $\begin{array}{l}\quad \text { Traits } \\
\text { OM } \\
\text { (ton/fed) }\end{array}$ & $\begin{array}{l}\text { Humic } \\
\text { App. }\end{array}$ & $\begin{array}{l}\text { Stem } \\
\text { length } \\
\text { (m) }\end{array}$ & $\begin{array}{l}\text { No. } \\
\text { lateral } \\
\text { stems } \\
\text { /plant }\end{array}$ & $\begin{array}{l}\text { Fresh weight } \\
\text { of } \quad \text { lateral } \\
\text { stem/plant } \\
(\mathbf{k g})\end{array}$ & $\begin{array}{l}\text { Total } \\
\text { yield } \\
(\text { Ton/fed) }\end{array}$ & $\begin{array}{l}\text { Tuber } \\
\text { fresh } \\
\text { weight } \\
\text { /plant (kg) }\end{array}$ & $\begin{array}{l}\text { Tuber } \\
\text { fresh } \\
\text { weight }(\mathrm{g})\end{array}$ & $\begin{array}{l}\text { Tuber } \\
\text { dry } \\
\text { matter\% }\end{array}$ \\
\hline \multirow{4}{*}{ 0 } & \multirow{4}{*}{$\begin{array}{l}\text { Spraying } \\
\text { Soil App. } \\
\text { Spraying+ } \\
\text { Soil App. }\end{array}$} & & & 2018 season & & & & \\
\hline & & 1.69 & 6.76 & 2.011 & 9.103 & 1.403 & 35.03 & 21.91 \\
\hline & & 1.74 & 6.80 & 2.085 & 9.365 & 1.483 & 37.15 & 23.12 \\
\hline & & 1.84 & 6.81 & 2.163 & 9.605 & 1.489 & 37.33 & 23.31 \\
\hline \multirow{3}{*}{5} & \multirow{3}{*}{$\begin{array}{l}\text { Spraying } \\
\text { Soil App. } \\
\text { Spraying+ } \\
\text { Soil App. }\end{array}$} & 1.78 & 7.61 & 2.091 & 10.173 & 1.543 & 38.66 & 22.03 \\
\hline & & 1.89 & 7.64 & 2.291 & 10.470 & 1.612 & 40.41 & 23.55 \\
\hline & & 1.93 & 7.53 & 2.312 & 10.853 & 1.689 & 42.31 & 23.67 \\
\hline \multirow{3}{*}{10} & Spraying & 1.81 & 7.74 & 2.153 & 10.873 & 1.635 & 41.53 & 22.29 \\
\hline & \multirow{5}{*}{$\begin{array}{l}\text { Soil App. } \\
\text { Spraying+ } \\
\text { Soil App. } \\
\text { Spraying } \\
\text { Soil App. } \\
\text { Spraying+ } \\
\text { Soil App. }\end{array}$} & 1.91 & 7.71 & 2.299 & 11.251 & 1.732 & 43.91 & 23.81 \\
\hline & & 1.93 & 7.68 & 2.388 & 11.783 & 1.873 & 47.03 & 23.89 \\
\hline \multirow{3}{*}{15} & & 1.85 & 7.75 & 2.167 & 11.536 & 1.762 & 44.16 & 22.45 \\
\hline & & 1.93 & 7.74 & 2.321 & 11.971 & 1.843 & 46.31 & 23.91 \\
\hline & & 1.97 & 7.73 & 2.599 & 12.381 & 1.953 & 50.03 & 24.01 \\
\hline LSD $_{0.05}$ & & 0.17 & $\mathrm{NS}$ & 0.131 & 0.311 & 0.124 & 2.21 & 0.64 \\
\hline \multirow{4}{*}{$\mathbf{0}$} & & & & 2019 season & & & & \\
\hline & Spraying & 1.59 & 6.40 & 1.642 & 8.732 & 1.357 & 33.08 & 20.08 \\
\hline & Soil App. & 1.61 & 6.31 & 1.721 & 8.981 & 1.347 & 33.19 & 22.32 \\
\hline & $\begin{array}{l}\text { Spraying+ } \\
\text { Soil App. }\end{array}$ & 1.72 & 6.42 & 1.803 & 9.211 & 1.397 & 34.09 & 22.76 \\
\hline \multirow{3}{*}{5} & Spraying & 1.68 & 6.43 & 1.853 & 9.703 & 1.463 & 35.67 & 20.65 \\
\hline & Soil App. & 1.71 & 6.51 & 1.895 & 9.951 & 1.509 & 36.92 & 22.59 \\
\hline & $\begin{array}{l}\text { Spraying+ } \\
\text { Soil App. }\end{array}$ & 1.90 & 6.71 & 1.966 & 10.250 & 1.563 & 38.12 & 23.09 \\
\hline \multirow{3}{*}{10} & Spraying & 1.72 & 6.81 & 1.973 & 10.543 & 1.633 & 40.91 & 21.09 \\
\hline & Soil App. & 1.83 & 6.78 & 2.069 & 10.871 & 1.691 & 41.35 & 22.89 \\
\hline & $\begin{array}{l}\text { Spraying+ } \\
\text { Soil App. }\end{array}$ & 1.91 & 6.73 & 2.103 & 11.053 & 1.700 & 42.18 & 23.36 \\
\hline \multirow{3}{*}{15} & Spraying & 1.75 & 7.23 & 2.108 & 11.003 & 1.691 & 42.37 & 21.15 \\
\hline & Soil App. & 1.84 & 7.31 & 2.110 & 11.431 & 1.735 & 43.63 & 22.99 \\
\hline & $\begin{array}{l}\text { Spraying+ } \\
\text { Soil App. }\end{array}$ & 1.97 & 7.34 & 2.118 & 11.541 & 1.786 & 43.12 & 23.49 \\
\hline LSD $_{0.05}$ & & 0.20 & $\mathrm{NS}$ & 0.089 & 0.251 & 0.103 & 2.36 & 0.42 \\
\hline
\end{tabular}




\section{Chemical constituents}

\subsection{Effect of organic manure:}

The results in Table (6) clearly show the effect of organic manure levels on chemical constituents of Jerusalem artichoke tubers N, P, K and inulin. The N, P, K, and inulin were increasing by excess of organic manure addition to soil in both seasons. The highest values of NPK and inulin percentage were obtained when the Jerusalem artichoke plants received organic manure at rate of 15 ton/fed compared with un-fertilized plant with organic manure during the two studied seasons. While the lowest NPK and inulin recorded in zero organic manure treatment. These results are in harmony with the results of ElSharkawy (2003), Ragab et al., (2008) and Anwar et al., (2011) on Jerusalem artichoke and Sharna and Arora (1990) and Arisha and Bardisi (1999) on Potato.

Table 6: Effect of organic manure on chemical contents of Jerusalem artichoke tubers at 2018 and 2019 seasons

\begin{tabular}{|c|c|c|c|c|c|c|c|c|}
\hline \multirow{3}{*}{$\begin{array}{c}\text { Organic } \\
\text { manure } \\
\text { (ton/fed) }\end{array}$} & \multicolumn{4}{|c|}{2018 season } & \multicolumn{4}{|c|}{2019 season } \\
\hline & $\mathbf{N}$ & $\mathbf{P}$ & $\mathbf{K}$ & Inulin & $\mathbf{N}$ & $\mathbf{P}$ & $\mathbf{K}$ & Inulin \\
\hline & $\%$ & $\%$ & $\%$ & $\%$ & $\%$ & $\%$ & $\%$ & $\%$ \\
\hline $\mathbf{0}$ & 1.14 & 0.31 & 1.33 & 10.41 & 1.09 & 0.24 & 1.30 & 10.07 \\
\hline 5 & 1.52 & 0.37 & 1.82 & 11.40 & 1.45 & 0.28 & 1.67 & 10.71 \\
\hline 10 & 1.80 & 0.41 & 2.01 & 11.90 & 1.73 & 0.33 & 1.96 & 11.04 \\
\hline 15 & 1.93 & 0.44 & 2.22 & 12.16 & 1.80 & 0.36 & 2.02 & 11.12 \\
\hline LSD $_{0.05}$ & 0.23 & 0.12 & 0.19 & 0.25 & 0.19 & 0.08 & 0.16 & 0.27 \\
\hline
\end{tabular}

\subsection{Effect of Humic acid:}

Chemical composition percentages of Jerusalem artichoke tubers were calculated in dry matter (Table 7). Results showed that, Potassium was significantly affected by humic acid application and insignificantly in nitrogen, phosphorus and inulin at 2018 season. Meanwhile, Potassium and inulin were significantly affected by humic acid application, and insignificantly in nitrogen and phosphorus contents.

These results may support the suggestion of humic acid stimulated capacity of action exchange as well as cell permeability of capillaries, leading to increase nutrient availability, enable better uptake of nutrients and act as plant growth parameters (O’Donnell, 1973 and Malcolm and Vaughan, 1979)

Table 7: Effect of humic acid application on chemical contents of Jerusalem artichoke tubers at 2018 and 2019 seasons.

\begin{tabular}{lcccccccc}
\hline \multirow{2}{*}{ Humic App. } & \multicolumn{4}{c}{ 2018 season } & \multicolumn{4}{c}{ 2019 season } \\
\cline { 2 - 9 } & $\mathbf{N \%}$ & $\mathbf{P \%}$ & $\mathbf{K \%}$ & Inulin\% & N\% & P\% & K\% & Inulin\% \\
\hline Spraying & 1.55 & 0.35 & 1.73 & 11.34 & 1.46 & 0.27 & 1.66 & 10.40 \\
Soil App. & 1.60 & 0.38 & 1.86 & 11.44 & 1.52 & 0.30 & 1.73 & 10.77 \\
Spraying+ Soil App. & 1.65 & 0.42 & 1.94 & 11.63 & 1.58 & 0.32 & 1.82 & 11.03 \\
LSD 0.05 & NS & NS & 0.11 & NS & NS & NS & 0.12 & 0.16 \\
\hline
\end{tabular}

\section{The interaction effect:}

The presented data in Table (8) indicated that there were significant differences among the treatments tested in these traits, NPK and inulin in tubers. Concerning the effect of spraying of Jerusalem artichoke with soil addition by humic acid, it gave the highest values when the plant received 15 ton/fed of organic manure in most characters. At the same time, no significant effect of this treatment on Nitrogen and Phosphorus in second season. 
Table 8: Effect of interaction between organic and humic acid application on chemical contents of Jerusalem artichoke tubers at 2018 and 2019 seasons.

\begin{tabular}{|c|c|c|c|c|c|c|c|c|c|}
\hline \multirow{3}{*}{$\begin{array}{l}\text { Organic } \\
\text { manure } \\
\text { (ton/fed) }\end{array}$} & \multirow[t]{3}{*}{ Humic App. } & \multicolumn{4}{|c|}{2018 season } & \multicolumn{4}{|c|}{2019 season } \\
\hline & & $\mathbf{N}$ & $\mathbf{P}$ & $\mathbf{K}$ & Inulin & $\mathbf{N}$ & $\mathbf{P}$ & $\mathbf{K}$ & Inulin \\
\hline & & $\%$ & $\%$ & $\%$ & $\%$ & $\%$ & $\%$ & $\%$ & $\%$ \\
\hline \multirow{3}{*}{$\mathbf{0}$} & Spraying & 1.12 & 0.27 & 1.30 & 10.37 & 1.03 & 0.21 & 1.26 & 9.83 \\
\hline & Soil App. & 1.13 & 0.31 & 1.32 & 10.11 & 1.08 & 0.23 & 1.31 & 10.12 \\
\hline & $\begin{array}{c}\text { Spraying+ Soil } \\
\text { App. }\end{array}$ & 1.17 & 0.34 & 1.36 & 10.46 & 1.15 & 0.27 & 1.32 & 10.25 \\
\hline \multirow{3}{*}{5} & Spraying & 1.48 & 0.34 & 1.74 & 11.28 & 1.41 & 0.25 & 1.61 & 10.35 \\
\hline & Soil App. & 1.52 & 0.37 & 1.83 & 11.32 & 1.46 & 0.29 & 1.69 & 10.79 \\
\hline & $\begin{array}{c}\text { Spraying+ Soil } \\
\text { App. }\end{array}$ & 1.57 & 0.40 & 1.89 & 11.59 & 1.49 & 0.31 & 1.71 & 10.99 \\
\hline \multirow{3}{*}{10} & Spraying & 1.72 & 0.37 & 1.85 & 11.68 & 1.68 & 0.29 & 1.83 & 10.65 \\
\hline & Soil App. & 1.81 & 0.41 & 2.04 & 11.89 & 1.72 & 0.33 & 1.91 & 11.03 \\
\hline & $\begin{array}{c}\text { Spraying+ Soil } \\
\text { App. }\end{array}$ & 1.86 & 0.46 & 2.14 & 12.13 & 1.79 & 0.37 & 2.13 & 11.44 \\
\hline \multirow{3}{*}{15} & Spraying & 1.88 & 0.40 & 2.03 & 12.01 & 1.73 & 0.31 & 1.93 & 10.77 \\
\hline & Soil App. & 1.93 & 0.44 & 2.25 & 12.13 & 1.81 & 0.36 & 2.01 & 11.15 \\
\hline & $\begin{array}{c}\text { Spraying+ Soil } \\
\text { App. }\end{array}$ & 1.99 & 0.48 & 2.38 & 12.33 & 1.87 & 0.41 & 2.12 & 11.43 \\
\hline LSD $_{0.05}$ & & 0.31 & 0.23 & 0.12 & 0.36 & NS & NS & 0.23 & 0.47 \\
\hline
\end{tabular}

\section{References}

Anwar, R.S.M., M.M.A. Ramadan and I.A.S. Al-Easily, 2011. Effect of different rates of farmyard manure and plant spacing on growth, yield and quality of Jerusalem artichoke plants under sandy soil conditions. J. Plant Production, Mansoura Univ., 2 (9): 1123 - 1135.

Arisha, H.M. and A. Bardisi, 1999. Effect of mineral and organic fertilizer on growth, yield and tuber quality of potato under sandy soil conditions. Zagazig J. Agric. Res. 20(2): 391-405.

Borin, M., G. Giupponi and F. Osele, 1987. The effect of organic and mineral fertilizer and soil type on potato tuber formation. In formation Agrario, 43: 91-92.

Brown, I.D. and O. Lilleland, 1946. Determination of potassium and sodium in plant material and soil extracts by flame photometry. Proc. Amer. Soc. Hort. Sci., 48: 341-346.

Cooke, G.W., 1972. Fertinizing foe maximum yield. Richarad clay (the chauer press). Bungary. Suffok, Great Britian, 457.

Eid, K., 2013. Field applications of some bioagents and safety chemicals to control stem rot disease of Jerusalem artichoke (Helianthus tuberosus L.). J. Appl. Sci. Res., 9(11): 5825-5834.

El-Sayed Hameda, E.A., A. Saif El Dean, S. Ezzat, and A.H.A. El Morsy, 2011. Responses of productivity and quality of sweet potato to phosphorus fertilizer rates and application methods of the humic acid. Int. Res. J. Agric. Sci. Soil Sci., 1: 383-393.

El-Desuky, M., 2004. Response of onion plants to humic acid and mineral fertilizers application. Annl. Agric. Sci., 42: 1955-1964.

El-Sharkawy, Z.A., 2003. Response of growth and yield of Jerusalem artichoke to different nitrogen sources and organic manure (FYM). J. Agric. Sci., Mansoura Univ., 28 (3): 2033-2051.

Gomez, K.A. and A.A. Gomez, 1984. Statistical Procedures for Agricultural Research. $2^{\text {nd }}$ Ed. John Wiley and Sons. Inc. New York, USA, 680.

Hafez, M. Magda, 2003. Effect of some sources of nitrogen fertilizer and concentration of humic acid on the productivity of squash plant. Egypt. J. Appl. Sci., 19: 293-309

Hallorans, G.M, M.A. Munoz and O. Colbera, 1993. Effect of chicken manure on chemical properties of a mollisal and tomato production. J. Agric. Univ. Puerto Rco. 77(3-4): 181 -191

Jafari-Jood, S., A.H. Shiranirad, J. Daneshian and A. Rokhzadi, 2013. Effects of nitrogen application and spraying of boron and manganese on growth traits of two potato cultivars. International Journal of Biosciences, 3(9): 298-303.

Kays, S.J. and S.F. Nottingham, 2008. Biology and Chemistry of Jeruslaem Artichoke (Helianthus tuberosus L.), CRC Press Taylor and Francis Group, New York, 478. 
Koch, F.G. and T.L. McMeckin, 1924. A new direct nesslerization micro-Keldahl method and a modification of the Nessler-Folin reagent for ammonia. J. Amer. Chem. Soc., 46: 2066.

Malcolm, R.E. and D. Vaughan, 1979. Effects of humic acid on invertase activities in plant tissues and their interaction with an invertase inhibitor. Soil Biol. Biochem., 11: 65-72

Maynard, A.A., 1989. Agricultural compost as an endments reduced nitrate leaching from soil. Frontiers of plant Sci., 42(1): 2-4.

Mengel, K. and E.A. Kirkby, 1978. Principles of Plant Nutrition, International Potash Institute, Bern, Switzerland.

Monti, A., M.T. Amaducci, and G. Venturi, 2005. Growth response, leaf gas exchange and fructans accumulation of Jerusalem artichoke (Helianthus tuberosus L.) as affected by different water regimes. Eur. J. Agron., 23 (2): 136-145.

O'Donnell, R.W., 1973. The auxin-like effects of humic preparations from leonardite. Soil Sci., 116: 106-112.

Ragab, M.E., Nadia M. Hamed, and Zohora A. El-Sharkawy, 2008. Response of Jerusalem artichoke (Helianthus tuberosus L.) Plants to some Bio and organic fertilization treatments in the new reclaimed lands. First International Conference of Agric. Sci. Consohdated of Role the Research in Sustainability Agricultural Development plants, 13-15 October 2008, Faculty Agric., Aleppo Univ., Syria.

Reynders, L. and K. Vlassak, 1982. Use of Azospirllum brasilense as bio-fertilizer in intensive wheat cropping. Plant and Soil, 66: 217-223.

Samy, M.M., Nagwa A. Mohamed and Mervat G. Abd El-Aziz, 2015. Effect of boron, copper and humic acid treatments on vegetative growth, yield and storability of Jerusalem artichoke tubers. J. Product. \& Dev., 20(3): 325- 342.

Seiler, J.G and L.G. Campbell, 2004. Genetic Variability for Mineral Element Concentrations of Wild Jerusalem artichoke Forage. Crop science, 44(1): 289-292.

Selim, E.M., S.I. Shedeed, F.F. Asaad, and A.S. El-Neklawy, 2011. Interactive effects of humic acid and water stress on chlorophyll and mineral nutrient contents of potato plants. J. Appl. Sci. Res., 7:531-537.

Sharma, V.C. and B.R. Arora, 1990. P and K uptake pattern in potato as affected by applied nitrogen. Madras Agric. J., 77(3-4): 125-130.

Tassoni, A., N. Bagni, M. Ferri, M. Franceschetti, A. Khomutov, M.P. Marques, S.M. Fiuza, A.R. Simonian, and F.D. Serafini, 2010. Helianthus tuberosus and polyamine research: Past and recent applications of a classical growth model. Plant Physiol. Bioch., 48 (7): 496-505.

Troug, E. and A.H. Meyer, 1939. Improvement in deiness colorimetric method for phosphorus and arsenic. Ind. Eng. Chem. Anal. Ed., 1: 136 - 139

Verlinden, G., B. Pycke, J. Mertens, F. Debersaques, K. Verheyen, G. Baert, J. Bries, and G. Haesaert, 2009. Application of humic substances results in consistent increases in crop yield and nutrient uptake. J. Plant Nutr., 32: 1407 -1426.

Winton, A.L. and K.B. Winton, 1958. The analysis of foods. John Wiley and Sons, Inc. London 857. 